\title{
SURFING THE INTERNET IN SEARCH OF CREATIVITY
}

\section{Panchenko O. I.}

\section{INTRODUCTION}

It is no doubt that we live in the information-oriented society which can be considered a new stage in the development of civilization which has got its own ways of creativity. Electronic means of communication have their own influence on humanity, and the degree of impact on human civilization development is quite comparable with the occurrence of writing and the invention of the printing press. The Internet as an information and communication platform has become essential in our normal daily life. One of the evidence of its scientific importance is the existence of variant terms for Internet language which include computer-mediated language, computermediated discourse, online discourse, and electronic discourse etc. All of these are intended to distinguish language- and discourse-related phenomena as a focus of interest from the broader phenomenon of computer-mediated communication, of which they form a part ${ }^{1}$.

"As a global information network, that potentially connects people around the world, the Internet has become a new myth - the myth of the unity of mankind. This utopia is born from the idea that the Internet overcomes the limitations of time, space and corporality. Geographic, national, racial and sexual differentiations are losing their significance there. It seems that the Internet is able to provide a harmonious coexistence of the total, inclusive society and the individual, isolated individual" 2 .

The relevance of the research is thus caused by growing interest of linguists to Internet innovations emergence, their interaction with other verbal and non-verbal components within and outside the network, peculiarities of creative activity on the Internet. The aim is to identify and analyze various means and genres of Internet creative activity. To achieve this aim during our study, it is expected to solve the following tasks: determine the types and ways of creation within the Internet; determine the

1 Herring S.C. Language and the Internet. The International Encyclopedia of Communication/ https://doi.org/10.1002/9781405186407.wbiecl005.

${ }^{2}$ Шмидт Э. Бестелесные радости. Проблемы тела, реальности, личности и языка в русскоязычном литературном Интернете. URL: http:www/litera.ru/slova/Schmidt/ radosti.html. 
notion and classification of creolized texts; analyze various types of creolized texts.

The language of the Internet has been studied for a long time (see papers by $\mathrm{Crystal}^{3}$, Herring ${ }^{4}$, Viotti ${ }^{5}$ etc. Besides various aspects of contemporary Internet communication have been in focus of the research by Blashki and $\mathrm{Nichol}^{6}$ who study the peculiarities of youth creativity on the Internet; Rice and Love $^{7}$ who investigate expression of emotions in a computermediated communication network; also mention Tagliamonte and Denis ${ }^{8}$ whose attention is paid to LOL language. This list is not complete, anyway we consider that the analysis of creativity on the Internet in comnnection with creolized text is worth special attention.

\section{Creolized text as a means of creation}

Contemporary life and the language development make researchers pay much attention to studying the texts with non-homogenous composition, the structure of which is a synthesis of natural languages with different semiotic systems; the text consisting of both verbal and non-verbal components. This text type in modern linguistics is called "creolized text". This term was first coined by Sorokin and Tarasov (1990). They define the concept in the following way: creolized text is "text, consisting of two non-homogeneous parts (verbal language (verbal) and non-verbal (belonging to other sign systems rather than natural language ${ }^{9}$. In other words, creolized text is the text that consists of two interconnected and interdependent components: verbal (language) and non-verbal (image, sound).

Creolized texts, as any other non-homogeneous text, are classified into various species according to the relationship nature of units that make up the structure. There are many various classifications, here is one of them.

\footnotetext{
${ }^{3}$ Crystal, David (2006). Language and the internet. 2nd edn. Cambridge: Cambridge University Press.

4 Herring S.C. Language and the Internet. The International Encyclopedia of Communication/ https://doi.org/10.1002/9781405186407.wbiec1005.

${ }^{5}$ Viotti, Vicki (1999). Language on the web. USA Today, December 23, ARC.

6 Blashki, Katherine, \& Nichol, Sophie (2005). Game geek's goss: Linguistic creativity in young males within an online university forum (94/M3 933k'5 9055oneone). Australian Journal of Emerging Technologies and Society 3:77-86.

${ }^{7}$ Rice, Ronald E., \& Love, Gail (1987). Electronic emotion: Socioemotional content in a computermediated communication network. Communication Research 14: 85-108.

8 Tagliamonte, Sali A., \& Denis, Derek (2008). Linguistic ruin? LOL! Instant messaging and teen language. American Speech 83:3-34.

9 Сорокин Ю.А., Тарасов Е.Ф. Креолизованные тексты и их коммуникативная функция. Оптимизация речевого воздействия. Москва, 1990. С. 180-181.
} 
According to Koltisheva, there exist three types of creolized texts ${ }^{10}$ : 1) interdependent texts, in which the structure of the verbal and pictorial components is equal and they are interpreted in conjunction with each other; 2) texts with the defining verbal component, where the image is dependent on the verbal component, and without this sense the image may be unclear or wrongly interpreted; 3) texts with the defining visual component, where the image plays a leading role in the theme disclosure and determines the interpretation of the verbal component. Thus, various kinds of correlations are installed between the verbal and non-verbal parts, there are several approaches to their description and classification in modern linguistics.

Anisimova considers the relationship of complementarity and interdependence between verbal and non-verbal parts of creolized texts. In case of complementary relationship, the image is clear without words, and can exist independently. Verbal comment is secondary, optional feature, as it only describes the image, duplicating its information. Relationship of interdependence mean that image depends on the verbal component, which determines its interpretation. The meaning of an image is unclear without comment, or it may be wrongly interpreted. In this case verbal comment performs the primary, basic function ${ }^{11}$. In addition to describing the various connections between verbal and non-verbal components in creolized texts, scientists consider it necessary to note the different degrees of their participation in the organization of the text. Anisimova identifies three main groups of creolized texts depending on the presence of the image and the nature of its connection with the verbal part: 1) text of zero creolization (no image at all), 2) texts with partial creolization; 3) text with full creolization. In texts with partial creolization, there are autosemantic relationships between verbal and non-verbal components, when the verbal part is relatively autonomous and independent from the image, and visual elements of the text are optional. This combination is often found in newspapers, popular-science and literary texts. In texts with full creolization verbal part cannot exist separately from the non-verbal component - there are synsemantic relationship between two components. Verbal part in this case is focused on the image or refers to it, and the image serves as an obligatory text element. This dependence is usually observed in advertising (posters,

\footnotetext{
${ }^{10}$ Колтышева Е.Ю. Креолизованная диктема как структурно-смысловой элемент рекламного текст. Вестник КГУ им. Н.А. Некрасова. 2008. № 1. С. 168-176.

11 Анисимова Е.Е. Лингвистика текста и межкультурная коммуникация (на материале креолизованных текстов) : учеб. пособие для студ. фак. иностр. яз. вузов. Москва : Academia, 2003. С. 12.
} 
cartoons, advertisements, etc.), as well as in academic and especially scientific and technical texts ${ }^{12}$.

Poymanova suggests distinguishing creolized (in the author's terminology - video-verbal) texts according to the ratio of the information volume, transmitted by various characters, and according to the role of images: 1) rehearsal - image usually repeats the verbal part; 2) additive - an image brings considerable additional information; 3) emphatic - an image "emphasizes" some aspect of verbal information, which is more meaningful than non-verbal part; 4) opposite - information, transmitted by the image contradicts with verbal information, it often causes comic effect; 5) integrative - the image is embedded in the verbal text or verbal text complements the image in order to transmit some joint information; 6) image-centric - with the leading role of the image, the verbal part only explains and elaborates $i^{13}$.

As a rule, researchers focus their attention on the color and the font used in the creation of the analyzed text. Color is one of the most important elements of creolized text: it attracts the recipient's attention (attractive function of colors), allows highlighting the most important, significant elements of the verbal component in relation to its semantics (meaning emphasizing function), as well influence human emotions (expressive function). Impact on the subconsciousness of the recipient provides also choice of a certain font size and typeface, as the font itself is a form of social coding, revealing the man relation to the various classes and groups. People use various font types according to fulfilment of different specific tasks, set by the sender, that define the basic functions of the font element in creolized texts. These include the attractive, meaning emphasizing, expressive, characterological, symbolic, satirical and aesthetic functions.

To sum up let us say, that on this stage creolized text is a comparatively new branch of study. For a long time this phenomenon has not attracted special and general attention of linguists, and traditionally narrow approach to that concept led to the fact that the analysis of creolized texts was reduced to individual observations of the images use in the book publishing, advertising and mass-media. A broad understanding of the text due to the communicative-pragmatic approach has led to a change in the status of creolized texts in linguistics, studying of their textual nature is the key point now. The starting point for such research is the provision of a fundamental

12 Анисимова Е.Е. Лингвистика текста и межкультурная коммуникация (на материале креолизованных текстов): учеб. пособие для студ. фак. иностр. яз. вузов. Москва : Academia, 2003. С. 15

13 Пойманова О.В. Семантическое пространство видеовербального текста. Москва, 1997. 237 с. 
similarity of creolized and proper verbal texts, therefore, they both have the same base text categories. This statement freed researchers and expanded the set of admissible "tools" for creolized text analysis. In modern works dealing with this or that creolized text form, scholars widely use traditional methods of verbal text analyzing: the description of the main text categories and their specifics, the description of cognitive and conceptual frameworks etc. Removing this restriction also allowed extending the meaning of the concept, and therefore the circle of the analyzed phenomena. This is significant step due to growing popularity of creolized texts on the Internet.

\section{Typical means of creolization}

The world of creolized texts is extremely diverse. They can be found in newspaper and journalistic texts, scientific and technical texts, instructions, illustrated literary texts, texts, advertising, posters, comic books, leaflets, etc. Creolized texts are presented in almost all life spheres, and are used at the same time as means of communication, and the culture carrier of people, social group etc. Creolized texts reflect the worldview and belief system of people, their values, aesthetic ideals, because their understanding or nonunderstanding depends on the general recipient's background. Creolized text is often used on the Internet. As the Internet considered to be the area where to be successful means to attract attention, one should use various types of text information coding. To be creative on the Internet media means catch the eye. Text creolization is a way to make verbal information more distinguishable, more noticeable among colorful Internet sites and pages. It can be done through traditional means of text accentuation (in bold, Italic, underlined, strikeout font), that in certain circumstances can be observed as the means of creolization text.

For example:

1. I have italicized the most important words of his thesis to make them noticeable.

2. I was approached by a fat man.

3. Read the text and find the translation of the underlined words.

Italicized text can also be used as an imitation of a handwritten note: "I'll be back! - was written on the fridge by Henry's hand". As means of creolization, other different ways of accentuation can be used. One can use a very compact font to give the reader an impression of closeness, cohesion. To produce extra influence not only on the recipient's conscious, but also on their subconsciousness, word meaning can be already encrypted in the way the words are written. Many different icons and logos can be found on the Internet. They usually present general idea of the following information, that is why its effectiveness directly depends not only on the text, but also on the image presented in the massage. 
As a rule, the non-verbal aspect of the message bears about the half of the message information load. Illustrations in creolized messages should attract the reader's attention, give them some idea of the subject, to create a favourable impression of the information contained, and, in the end, make him become interested, whether it means to read the text or advertisement, or to use some link. Psychology studies how people perceive the message as follows: 1) at first, they look at the illustration; 2) then read the headline; 3 ) and finally, read the text message.

It is noted that the number of people reading the headlines is five times more than the number of people reading the main text. This means that combining headline (text) component with image component can be very successful.

To illustrate the abovementioned ideas we suggest considering some specific Internet creolized genres.

\section{Google Doodle}

\section{Creative genres on the Internet}

Google Search, commonly referred to as Google Web Search or simply Google, is a web search engine developed by Google. It is the most-used search engine on the World Wide Web, handling more than three billion searches each day. As of February 2016 it is the most used search engine in the US with $64.0 \%$ market share ${ }^{14}$.

However, it is known not only as a search tool, but also as a very creative Internet-source. On certain occasions, the logo on Google's webpage changes to a special version, known as a "Google Doodle". This is a picture, drawing, or animation that includes the logo. It is usually done for a special event or day although not all of them are well known. Clicking on the Doodle links to a string of Google search results about the topic. They can be dedicated to the birthdays of notable people like Albert Einstein, historical events like the interlocking Lego block's 50th anniversary and holidays like Valentine's Day (2021).

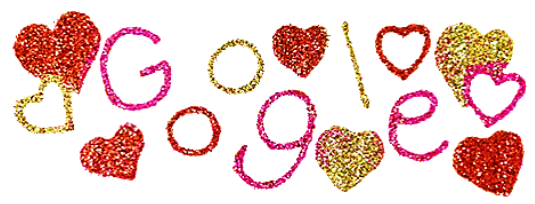

${ }^{14}$ ComScore.com - Releases February 2016 // U.S. Desktop Search Engine Rankings. Режим доступу: https://www.comscore.com/Insights/Rankings/comScore-ReleasesFebruary-2016-US-Desktop-Search-Engine-Rankings. 
Doodles has not only international, but also regional character. For example, on the Independence Day of Ukraine 2019 Google presented the logo, connotational meaning of which can be easily decrypted by Ukrainian people: reimaged the logo as a traditional Ukrainian rushnyk (towel). Embroidery has ancient roots in Ukraine, and so does the cultural significance of the kalyna digitally stitched into the center of that Doodle. This flowery shrub features prominently in Ukrainian literature, music, and folklore as a symbol of posterity and irrevocable family bonds, and often appears on the rushnyks sewn to celebrate Ukrainian births and weddings.

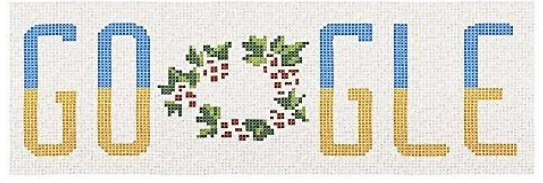

Word an image

Korean designer $\mathrm{Ji}$ Lee worked as a creative director at Google, Facebook and Instagram. His most outstanding and popular work is the project "Word as images". Lee draws words using characters that always convey the essence of the word ${ }^{15}$.

\section{FAST FOOD}

On this example, text gradually changes from normal font into tracing in bold, transferring with this the idea of becoming fat, consuming fast food. The next work of Ji Lee gives the full idea of how the climate changes. The word "change" is already partially disappeared, as many various animal spices that are at serious risk of extinction.

\section{CLIMATE \\ CUMMIrE}

15 Web Design Blog - Webdesigner Depot. Words as images. URL: http://www.webdesignerdepot.com/2013/03/words-as-images/. 
Images made out words. Tag clouds

Creolized texts can constitute an image themselves. There are even various programs (e.g. Tegxedo) that give an opportunity for a not very skilled person to obtain, for example, creative advert. Such unusual presentation of the world map can attract recipient's attention and become a highlight of the travel agency site.

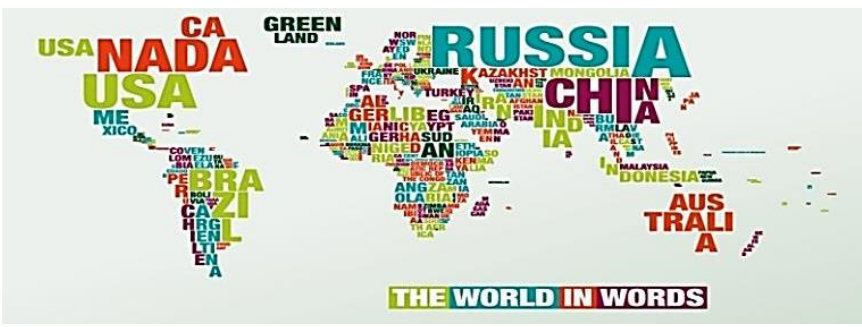

On the next example, the main lines of Justin Timberlake's face are recognizable. Looking closer, one can see the words from his the most famous songs ("What goes around, comes around", "Cry me a river", "Sexy back" etc.).

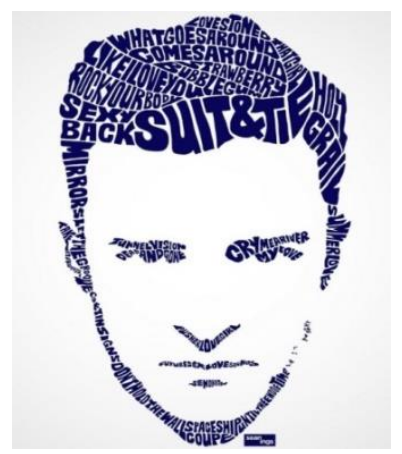

That style of the text presentation is often used in design of tag clouds.

A tag cloud (word cloud, or weighted list in visual design) is a visual representation of text data, typically used to depict keyword metadata (tags) on websites, or to visualize free form text. Tags are usually single words, and the importance of each tag is shown with font size or color. This format is useful for quickly perceiving the most prominent terms and for locating a term alphabetically to determine its relative prominence. When used as 
website navigation aids, the terms are hyperlinked to items associated with the $\operatorname{tag}^{16}$.

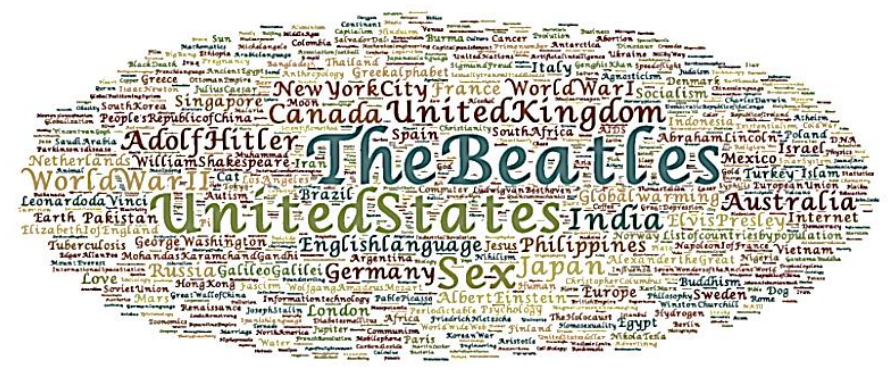

On this image you can see a tag cloud, constructed from Wikipedia's top 1000 vital articles sorted by number of views.

\section{Comics}

Comics is a medium used to express ideas by images, often combined with text or other visual information. Comics frequently takes the form of juxtaposed sequences of panels of images. Often textual devices such as speech balloons, captions, and onomatopoeia indicate dialogue, narration, sound effects, or other information. Size and arrangement of panels contribute to narrative pacing. Cartooning and similar forms of illustration are the most common image-making means in comics; fumetti (photonovels, photo comics) is a form, which uses photographic images. Common forms of comics include comic strips, editorial and gag cartoons, and comic books. Since the late 20th century, bound volumes such as graphic novels, comic albums etc have become increasingly common, and online web comics have proliferated in the 21 st century. Colloquial language is generally used in the dialogues, they are laconic, and the information, presented in the comics, is emotionally colored that contributes much in efficient absorption. Comics is also considered to be an example of creolized texts. Comics is also characterized by a strict compositional structure that distinguishes it from other types of texts. This is reflected in the content-compositional level: image component associated with the whole message, image and the verbal parts are located in one visual field. The text of this type is closer than others to traditional creolized texts (such as illustrations for works of art), the only difference is minimalism in design and comic effect. The image in the

\footnotetext{
${ }^{16}$ Halvey Martin An Assessment of Tag Presentation Techniques (poster presentation at WWW 2007) / Martin Halvey and Mark T. Keane. URL: http://www2007.org/htmlposters/poster988/.
} 
comics performs an attraction function, its simplicity and accessibility of content is designed to solve communication problems. The iconic component of the comics carries information about the dialogue participants, about the situation and performs an informative function. To create a comic effect without an image is extremely difficult. Satirical image function is implemented in a comic effect: the specificity of man's work requires constantly reproducing the words vice versa.

One of the defining features of the comics is an illustrative function. It gives an opportunity to present information, expressed verbally, with the help of visual images in whole or partially.

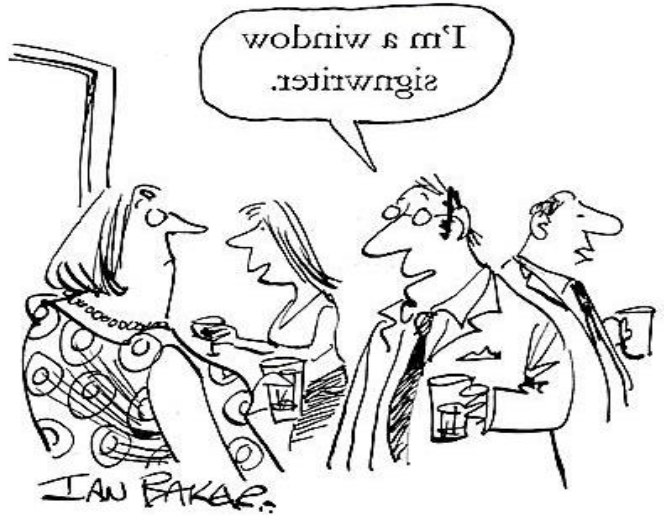

This creolized text is characterized by full creolization, because verbal part has no meaning without its verbal implementation.

The next comics is characterized by partial creolization, the joke itself is meaningful, but the image gives it extra emotional coloring.

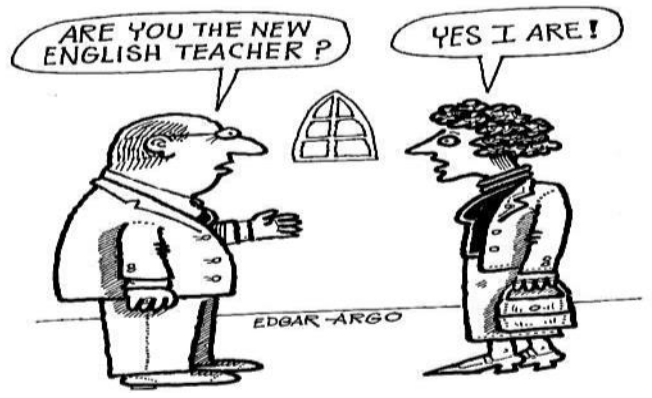




\section{Meme}

A meme is "an idea, behaviour, or style that spreads from person to person within a culture". A meme acts as a unit for carrying cultural ideas, symbols, or practices that can be transmitted from one mind to another through writing, speech, gestures, rituals, or other imitable phenomena with a mimicked theme. Supporters of the concept regard memes as cultural analogues to genes in that they self-replicate, mutate, and respond to selective pressures ${ }^{17}$.

The term "meme" was introduced by R. Dawkins, who first suggested the concept of the replicator in addition to the socio-cultural processes, "Examples of memes are tunes, ideas, buzzwords and expressions, ways of soup cooking or of arches building. Just as genes propagate in the genetic pool by leaping from one body to another by means of sperm or ovicell, memes spread in the same way, moving from one brain to another by a process, which in a broad sense may be called "imitation". In a broad sense, the meme is considered as a mechanism for the transmission and storage of cultural information. The main feature of a meme - the ability to replicate, that is to copy itself ${ }^{18}$.

The Internet is so important technology for the memes emergence, that those ones, that are actively distributed on the Internet, received an appropriate name - Internet-memes, although obviously, jokes, anecdotes and other popular "creative products" has successfully spread in other ways before the Internet popularity. So, Internet meme (or Internet phenomenon) - unit of information, an object that has gained popularity - usually spontaneously - in the information technology environment.

Spontaneous uncontrolled proliferation is not subject to any information among Internet users, but only that one, that somehow affects many people, makes them interested, or generates any associations. Sources of memes are the variety of online communities (blogs, forums, chat rooms, social networking groups, etc). Internet memes are of varying locality, depending on what part of the Internet space they cover. At first sight they usually remain incomprehensible for uninitiated person, if not accompanied with necessary explanations and, accordingly, do not cause the reaction of laughter. Primary sources of memes diversity: hot news in the media, art pieces (Mona Lisa), the film (Sparta), an anime character, the Internet user's saying, etc.

As a kind of precedent phenomena, Internet memes retain the information about the text resource, a cultural phenomenon or a historic event, which served as the source for the meme emergence. Hence, meme has a cultural connotation, providing the addressee the ability to identify the case of precedent phenomenon. The effectiveness of communication in this case is

\footnotetext{
${ }^{17}$ Graham G. Genes: a philosophical inquiry. New York : Routledge, 2002. 196 p.

18 Докинз Р. Эгоистичный ген. Москва : Мир, 1993. 318 с.
} 
directly related to the ability of Internet user to carry out an explication of hidden cultural meme connotations, and to restore those associative links, which provide comic effect ${ }^{19}$.

Important is the deliberate restriction of the focus group, which can understand it: this may be a specific group of people, united within the profession or social framework, users of one forum etc. For example, jokes on entertainment site, known as "Runet Quoter", according to the authors, was intended for programmers and similar audience.

This humor is "not for everyone", but only for those "who understands": the comic effect is intended for a specific audience. However, due to the openness of the Internet-meme space, it often becomes known to the general audience, breaking the limit that is of particular interest for the study.

Nowadays more complex structures are spread through the Internet, in which verbal and non-verbal elements form one visual, structural, semantic and functional unit, intended for the complex impact on the recipient creolized formation. Opportunities to achieve some comic effect in this case is due to the organic interaction of verbal and image parts. In modern Internet the following types of Internet-memes are functioning: text meme: a word or phrase; image-meme; video-meme; creolized meme, consisting of text and visual parts.

Text memes are words or phrases, used in public culture. The sources of their appearance are often the expressions of "ordinary" users. Here can be listed such examples as: LOL - laughing out loud.

Image-memes are recognizable images. Here could be considered Cthulhu, Trollface etc.
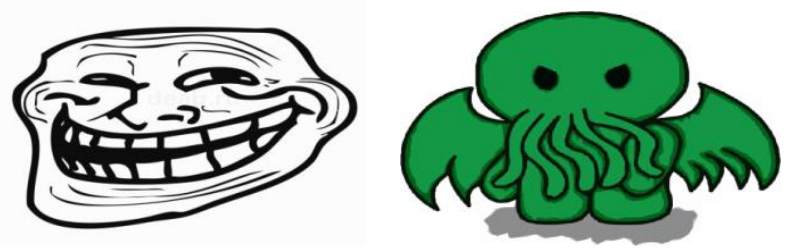

\section{Trollface}

Image "trollface", created in 2008 by user "Whynne" on DeviantArt site for web comics, is often used to refer to trolling in the modern Internet

19 Щурина Ю.В. Прецедентные элементы в структуре малых речевых жанров комического. Российский лингвистический ежегодник. 2006. Вып. 1(8). Красноярск, 2006. C. $77-84$. 
culture $^{20}$. In Internet slang, a troll is a person who sows discord on the Internet by starting arguments or upsetting people, by posting inflammatory, extraneous, or off-topic messages in an online community (such as a newsgroup, forum, chat room, or blog) with the intent of provoking readers into an emotional response or of otherwise disrupting normal, on-topic discussion often for the troll's amusement.

Cthulhu is a fictional cosmic entity created by writer H. P. Lovecraft and first introduced in the short story "The Call of Cthulhu". Lovecraft depicts Cthulhu as a gigantic entity worshipped by cultists. Cthulhu's appearance is described as looking like an octopus, a dragon and a caricature of human form. Considered a Great Old One within the pantheon of Lovecraftian cosmic entities, the creature has since been featured in numerous popular culture references. Different unnatural, even for this creature, actions were prescribed for the monster, such as human brain consuming etc. Cthulhu has become the subject of many cartoons, anecdotes, jokes and parodies. It has obtained even its own emoticon: $(; ;)^{21}$.

Video-meme

Video-meme is a comic video that are placed on the personal pages of social network users and are sent to each other via e-mail etc. The specificity of their use is in repeated playing and viewing, including collective. Their popularity is estimated by number of views. It is noteworthy that some video-memes conceived and shot as a parody, and others, on the contrary, become a comic source unexpectedly.

For example, a well-known meme "Mr. Trololo", emerged in 1967 from the video of the Soviet pop singer Eduard Khil. The singer has executed a vocalize, some parts of which sound like "ololo" or "Trololo" and nowadays is perceived as a reference to the modern Internet slang. In 2009 a video was posted on YouTube and has become an international Internet phenomenon.
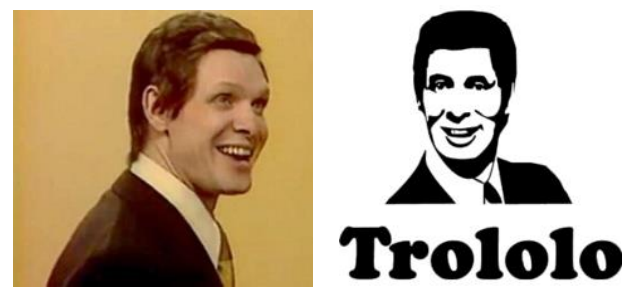

${ }^{20}$ Know Your Meme: Trollface. URL: http://www.webcitation.org/6CV2LWgLy.

${ }^{21}$ Lovecraft. H.P. Selected Letters of H. P. Lovecraft IV (1932-1934). Letter 617. Sauk City, Wisconsin: Arkham House, 1967. 424 p. 
Creolized meme is a variety of creolized texts. The main components are verbal part (label / signature) and image part (drawing, photography, and schedule). In various types of text they are found in various combinations. In the following example it is played on the frequent orthographic mistake in writing of the word GREAT which is homonym to the word GRATE etc.

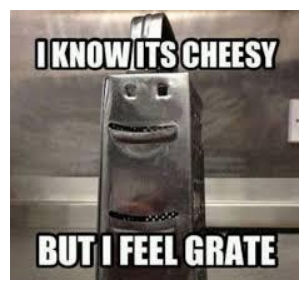

\section{Internet comics}

Forums' communication produced also new characteristic type of comics. The content of the online comic diverse: from comical to absurd situations on the most burning issues of the day. The iconic component in these texts is intended to illustrate the verbal text. For example, in this online comics the iconic part of the relatively static (the same background), changes occur with a person character. It shows a normal situation for modern social networks user. This creolized text has partial creolization. The verbal part is the relatively autonomous and can produce a comic effect without correlating with the visual component.

The most important task of comics lies in the necessity to express as much as possible information in a clear, visual way and to accompany it with the right quantities of replicas. The reader, while perceiving comics, processes organically both image and text, causing new level of generalization in perceiving.

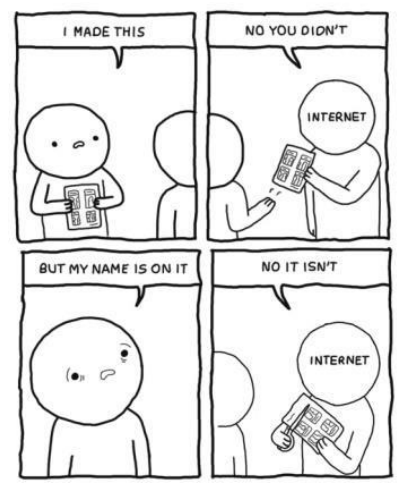


The next comics illustrates a normal situation on the Internet. Whatever the source or the author has the information, it can be reposted under another initial data.

The comics' structure can be simple and colorless, or it can obtain form that is more complicated. However, usually it has simple structure, sketchy drawing and often contains duplicate items. Memes often become part of the comics, it's also one of the most prominent feature of that genre.

"True story"-meme is usually placed at the end of the comics, confirming the truth of history, although in reality the story may be a lie or a fantasy.

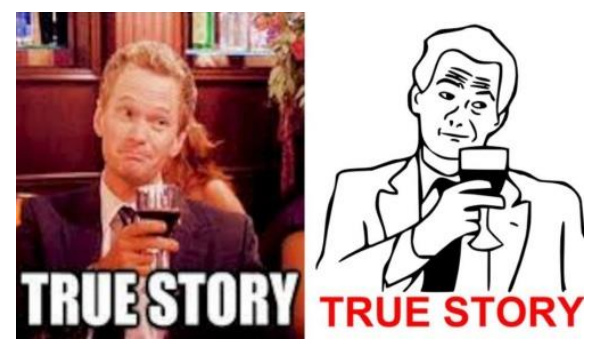

\section{Demotivator}

Demotivator (demotivating poster) is an image consisting of picture in a frame, and a comment, composed under a specific format. Demotivational posters appeared as a parody of motivational posters, or motivators - popular in the US kind of visual propaganda, designed to create an appropriate mood in schools, universities and workshops ${ }^{22}$. As a parody of motivational posters, demotivators spread widely. Demotivators are drawings of the same standard, but are intended to cause the opposite emotions: despair, despondency and sadness. Subsequently demotivators' themes expanded to simply comic.

Genre of demotivational posters requires strict adherence to the format of an image build-up: poster is almost always in black; image in a frame; slogan, dialled in large fonts including serif; explanation or citation explaining the slogan's idea, typed in a smaller font (sometimes is absent). Many slogans, used in demotivators, become Internet memes. For the production and perception of demotivators it is necessary to have not only a sense of humor, but also the ability to see events from a different

22 Голиков А.С. Демотиваторы в интернет-коммуникации: генезис, смыслы, типология. Вестник Харьковского государственного университета. 2010. Вып. 16. C. $124-130$. 
perspective. Verbal parts of that creolized text function well even without image part in everyday speech.

\section{QR code}

The last researches have also a tendency to understand QR code as a type of creolized text. This square bar code is a development of subsidiary of Japanese concern Toyota and was originally used for logistical purposes. QR code (quick response) code is a matrix or, in other words, a two-dimensional bar code. To "read" the information thus provided, the recipient has to use a mobile phone with a camera and special software. After photographing this code, the recipient almost instantly receives all the necessary information this could be the site of the advertiser, video, map, text information, etc. In Japan, QR codes are used even in cemeteries and contain information about the deceased ${ }^{23}$. The example illustrates the inclusion of all three components of creolized text. On the following picture, a QR code is a creolized text itself. This hypercode includes a verbal part "You are here". "The map" and the image part - gives a recipient an idea of what he will get after "reading" of the $\mathrm{QR}$ code.

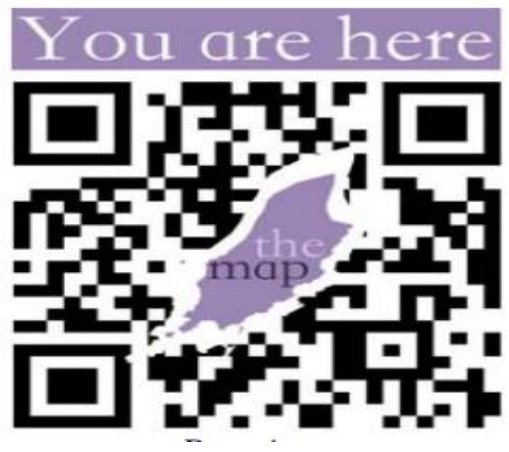

QR code can be used in the texts without any verbal or image component and even stand alone as creolized text, including visual and verbal components.

Thus it can be said, that creolized texts are gaining their popularity. Due to quick information transmission and perception, and extraordinary appearance, such non-homogeneous type of information is easy to find almost everywhere within Internet.

${ }^{23}$ KAROKAN 2.0 - о реальном и виртуальном. QR коды на кладбищах. URL: http://karokan.livejournal.com/25755.html. 


\section{CONCLUSIONS}

The growing role of the Internet causes the growth of interest of linguists to Internet innovations and creative units. We identified main means and genres of Internet creative activity, the role of creolized texts in particular. Creolized texts are other non-homogeneous ones consisting of verbal and non-verbal parts which can be classified according to the relationship nature of units that make up the structure. They demonstrate growing popularity on the Internet as the attention of the Internet users first of all is drawn by the image form of a text including its fonts, colours and images.

We have considered some specific popular Internet creolized genres such as Google Doodle, word as an image, a tag cloud (word cloud, or weighted list in visual design), Internet-memes, including creolized meme, demotivator (demotivating poster) and QR code.

All these are a variety of creolized texts. The main components are verbal part (label / signature) and image part (drawing, photography, and schedule). In various types of text they are found in various combinations. The text of this type is close to traditional creolized texts (such as illustrations for works of art), the only difference is minimalism in design and comic effect. They may be a visual representation of text data, typically used to depict keyword metadata on websites, or to visualize free form text.

Thus the Internet area is the inexhaustible source of creativity which can be useful for different purposes: enjoying ones selves, learning creative means, reusing them in one's own creative activity.

\section{SUMMARY}

The article deals with the peculiarities of creative activity on the Internet. It has determined the notion of creolized texts as a powerful means of organizing creative linguistic activity. Such texts increase the interest of the Internet users to the information presented on it. They also promote the popularity of this or that site. The article deals with various kinds of contemporary creative Internet genres. These are Google Doodle, meme (Internet meme, creolized meme), comics, Trololo and Cthulhu, QR-codes etc. Attention is drawn to their formal and content peculiarities. analysed. The article emphasizes the role of new texts and genres in creative linguistic activity in general.

\section{REFERENCES}

1. Анисимова Е.Е. Лингвистика текста и межкультурная коммуникация (на материале креолизованных текстов): учеб. пособие для студ. фак. иностр. яз. вузов. Москва : Academia, 2003. 128 с. 
2. Голиков А.С., Калашникова А.А. Демотиваторы в интернеткоммуникации: генезис, смыслы, типология. Вестник Харьковского государственного университета. 2010. Вып. 16. С. 124-130.

3. Докинз Р. Эгоистичный ген. Москва : Мир, 1993. 318 с.

4. Колтышева Е.Ю. Креолизованная диктема как структурносмысловой элемент рекламного текста. Вестник КГУ им. Н. А. Некрасова. 2008. № 1.264 с.

5. Пойманова О.В. Семантическое пространство видеовербального текста. Москва, 1997. 237 с.

6. Сорокин Ю.А., Тарасов Е.Ф. Креолизованные тексты и их коммуникативная функция. Оптимизация речевого воздействия. Москва, 1990. $240 \mathrm{c.}$

7. Шмидт Э. Бестелесные радости. Проблемы тела, реальности, личности и языка в русскоязычном литературном Интернете. URL: http:www/litera.ru/slova/Schmidt/radosti.html.

8. Щурина Ю.В. Прецедентные элементы в структуре малых речевых жанров комического. Российский лингвистический ежегодник. 2006. Вып. 1(8). Научное издание. Красноярск, 2006. С. 77-84.

9. Blashki, Katherine, \& Nichol, Sophie. Game geek's goss: Linguistic creativity in young males within an online university forum (94/M3 933k'5 9055oneone). Australian Journal of Emerging Technologies and Society 36 2005. Pp. 77-86.

10. ComScore.com - Releases February 2016 // U.S. Desktop Search Engine Rankings. URL: https://www.comscore.com/Insights/Rankings/ comScore-Releases-February-2016-US-Desktop-Search-Engine-Rankings.

11. Crystal, David. Language and the internet. 2nd edn. Cambridge: Cambridge University Press. 2006.

12. Graham G. Genes: a philosophical inquiry. New York, 2002. 196 p.

13. Martin Halvey and Mark T. Keane. An Assessment of Tag Presentation Techniques (poster presentation at WWW 2007). URL: http://www2007.org/htmlposters/poster988/.

14. Herring S.C. Language and the Internet. The International Encyclopedia of Communication/ https://doi.org/10.1002/ 9781405186407.wbiec1005.

15. KAROKAN 2.0 - о реальном и виртуальном. QR коды на кладбищах. Режим доступу: http://karokan.livejournal.com/25755.html.

16. Know Your Meme: Trollface. URL: http://www.webcitation.org/ 6CV2LWgLy.

17. Lovecraft H.P. Selected Letters of H. P. Lovecraft IV (1932-1934). Letter 617 Sauk City, Wisconsin : Arkham House, 1967. 424 p. 
18. Rice, Ronald E., \& Love, Gail. Electronic emotion: Socioemotional content in a computermediated communication network. Communication Research 14, 1987. Pp. 85-108.

19. Tagliamonte, Sali A., \& Denis, Derek. Linguistic ruin? LOL! Instant messaging and teen language. American Speech 83, 2008. Pp. 3-34.

20. Viotti Vicki. Language on the web. USA Today, December 23, 1999.

21. Web Design Blog - Webdesigner Depot. Words as images. URL: http://www.webdesignerdepot.com/2013/03/words-as-images/.

\section{Information about the author:} Panchenko O. I., Doctor of Philology, Professor at the Department of Translation, and Linguistic Training of Foreigners Oles Honchar Dnipro National University 72, Gagarin Avenue, Dnipro, 49010, Ukraine 